\title{
Family and Community Dynamics That Contribute to Female Involvement in Terrorist Activity in Nigeria
}

\author{
Peculiar M. Awa \\ Correspondence: Peculiar M. Awa, University of Central Missouri, USA. \\ Received: October 29, 2021 \\ Accepted: December 3, $2021 \quad$ Online Published: December 7, 2021 \\ doi:10.11114/ijlpa.v4i2.5419 \\ URL: https://doi.org/10.11114/ijlpa.v4i2.5419
}

\begin{abstract}
Since 2013, Boko Haram has significantly contributed to gendered violence against women. This study examines the experiences of 16 women and girls who lived in the Boko Haram camp from 2014-2018 and had varying levels of engagement in the organization's activities. The study employs a qualitative phenomenological in-depth interview methodology. Semi-structured interviews conducted in Nigeria yielded data on the respondents' experiences before, during, and after their times with Boko Haram. Based on the analysis of interview responses and field notes, several themes emerged. Overall findings suggest that family and community dynamics play a significant role in terrorism in Nigeria. More specifically, early child marriage and the lack of access to education increase girls' vulnerability to abductions by Boko Haram, which, in turn, contributes to involvement in terrorism. Boko Haram members take control over the most disadvantaged and vulnerable victims and, through direct threats or non-consensual marriage, force these women to succumb to their pressure. Respondents reported facing barriers to reintegration into the community, although those with more formal education tended to fare better. These findings are discussed in terms of their implications for future research and counter-terrorism efforts in Nigeria.
\end{abstract}

Keywords: Gender, Abduction, Boko Haram, Nigeria, Terrorism

\section{Introduction}

On April 14, 2014, a group of militants known as Boko Haram attacked the Government Girls Secondary School in Chibok, Nigeria, kidnapping 276 schoolgirls. This incident stirred up a global outcry and increased public awareness of violence against women and girls in Nigeria. However, this global awareness also inspired Boko Haram to begin deploying women as suicide bombers (Bloom \& Matfess, 2016). Boko Haram continues to kidnap women and girls. As recently as in February 2018, the organization abducted 111 girls from the Government Girls Science and Technical College in Dapchi, Yobe state, located in the North-Eastern part of Nigeria.

Boko Haram has used more women and girls in their bombing attacks than any other terrorist organization in history. Between June 2014 and January 2016, Boko Haram carried out 89 attacks against civilian soft targets, in which they used women or girls. The organization has deployed approximately 244 female suicide bombers since 2014 (Aziz, 2017). While terrorist organizations in other countries (e.g., Sri Lanka) and regions (e.g., Middle East) have employed female operatives, Boko Haram's use of women and girls has been even greater and unprecedented in scale. For example, throughout its ten-year history, the Tamil Tigers utilized 46 women, while Boko Haram deployed more than 90 women and girls in 18 months, from June 2014 to January 2016 (Steward, 2015).

Women in terrorist groups represent an understudied phenomenon. As a result, the notion that female participation in terrorism is a recent phenomenon is promoted (Cunningham, 2007; Agara, 2015). Consequently, there are many unanswered questions about female involvement in terrorist groups, including myriad concerns about women's recruitment, radicalization, roles, or perspectives on terrorism. Typically, women are considered passive or coerced actors in terrorism rather than active perpetrators of violence (Cunningham, 2003; Ness, 2007; Talbot, 2000). This perception hinders counter-terrorism policies and perpetuates gendered assumptions about women's roles in terrorist groups.

The rise in the insurgency in Nigeria has significantly changed the lives of thousands of women and girls, casting them into roles that fall outside the ambit of domestic spheres. While men perpetrate most violent acts, women and girls make up most of the estimated 1.8 million Internally Displaced Persons (IDP) in the North-Eastern part of Nigeria. The analysis of women and girls involved in violence in Nigeria remains limited by the lack of research (Zenn \& Pearson, 2014). There is a compelling need for more research with and about women in captivity or collaborating with terrorists to ascertain their views, 
experiences, motivations, and contributions to specific attacks. Understanding how women experience the conflict in Nigeria both as victims and actors can directly inform policies and programs to tackle insurgency at the roots. This study aims to explore the role of women in terrorism in Nigeria as a path to preventing the country's ongoing and escalating violence.

In the following section, the literature is reviewed. Afterward, the details of this phenomenological study are presented, and the data source is introduced. Then, descriptive information on the process and procedures utilized in the study are presented, and the significant findings are discussed. The paper concludes with policy implications and recommendations for future research.

\subsection{Background}

With the 2014 abduction of the Chibok schoolgirls and the continued kidnapping of women and girls, Boko Haram's use of female suicide bombers increased. This development signifies the organization's adoption of a gendered approach towards actualizing its goals (Maiangwa \& Agbiboa, 2014). Scholars have attributed the reason behind the rise in the abduction and use of women by Boko Haram to the declaration of the state of emergency by the Goodluck Jonathan administration in May 2013 (Zenn \& Pearson, 2014; Bloom \& Matfess, 2016; Awa, 2020). Research contends that the use of kidnapping as a tactic by the sect began after a raid by federal forces led to the arrest of family members of suspected sect members and over a hundred women, including the wives of Abubakar Shekau, Boko Haram's leader at the time. Consequently, the group's leader issued a threat in January 2014 to engage in a gender-based abduction centered mainly on the kidnapping of women (Barkindo, Gudaku, \& Wesley, 2013).

Subsequently, the victimization of women and Gender-Based Violence (GBV) became an overt aspect of the activities of Boko Haram (Zenn and Pearson, 2014; Human Rights Watch, 2014; Osita-Njoku \& Chikere, 2015; Maiangwa and Amao, 2015; Awa, 2020). While sexual violence against women and the incorporation of gender into violent movements is a global issue, the increase in female participation in terrorist activity in Nigeria builds upon a history of tactical experimentation undertaken in response to the government's reactions to the insurgents. The adoption of female fighters served as a means for Boko Haram to distinguish itself from other terrorist organizations in Nigeria (Bloom \& Mattfess, 2016). The perception is that the organization's reliance upon women and girls is part of their organizational shift, which utilizes coerced participation to generate support to actualize their goals (Zenn \& Pearson, 2014; Osita-Njoku \& Chikere, 2015). Other parts of Sub-Saharan Africa where rebel movements thrived have tactically exploited women. For example, the civil conflicts in Mozambique, Sierra Leone, and Rwanda witnessed the abduction, sexual violence, forced marriage, and conscription of enemy women into insurgent groups (Lord-Mallam, 2019; Turshen, 2001). The active involvement of women in Boko Haram's activities has grown to substantially become a matter of public attention across the globe (Sjoberg et al., 2011). This aspect of terrorism represents a novel but a growing trend (Pape, 2005).

Terrorism research in Nigeria is still developing and has faced some difficulty. A lack of information and adequate data on terrorist incidents is necessary to analyze the problem and efficiently develop counter-terrorism strategies (Awa, 2020). Additionally, the illiteracy of prospective respondents, incomplete statistics, scanty information bases, inaccurate census figures, and insufficient funds continues to hinder terrorism research in Nigeria. As a result, research efforts into the subject matter of female participation in terrorism in Nigeria have been too scanty to develop an empirical foundation for this study to build on. Hence, this study contributes to the literature by taking a phenomenological approach to understanding the factors influencing female involvement with terrorists in Nigeria. A phenomenological study of this nature is necessary to form a foundation for the understanding of the phenomenon.

\subsection{The Intersection between Stockholm Syndrome and the Rational Choice Theory of Terrorism}

Behavioral patterns that occur because of Stockholm Syndrome could fall within the ambit of the Rational Choice Theory of Terrorism. The prospect of an intersection between these two theories can account for female involvement in terrorist activity in Nigeria. The Rational Choice Theory of Terrorism is a psychological theory that seeks to account for the engagement in terrorist activity (Berrebi, 2009). According to the rational choice theory of terrorism, terrorist acts stem from individuals' sound, conscious, and calculated decisions. This theory also holds that terrorist acts embody an optimal strategy to fulfill the sociopolitical goals of the perpetrators (Anderton \& Carter, 2005). Hence, terrorism might not represent irrational or unreasoned human behavior, but it could represent an individual's best means of achieving personal needs.

On the other hand, Stockholm Syndrome presents an explanation for engagement in terrorism from a victim's perspective. It is a psychological response to severe trauma. Adorjan, Christensen, Kelly, and Pawluch (2012) explain that Stockholm Syndrome is a coping mechanism that involves psychological adjustments adopted by individuals lacking personal freedom. Researchers have argued that Stockholm Syndrome relies on psychological dynamics through which victims identify with their captors (Ochberg, 1982; Adorjan, Christensen, Kelly, \& Pawluch, 2012). Given the traumatic effects of kidnapping, Stockholm Syndrome can explain female participation in terrorist activity in Nigeria in instances where victims of Boko Haram's kidnapping begin to exhibit behaviors that mirror the Rational Choice Theory of Terrorism. 
The intersection between the Stockholm Syndrome and the Rational Choice Theory of Terrorism can readily account for a blurred line between victimization and perpetuation surrounding the subject matter of female engagement in terrorist activity in Nigeria. Approaching the subject matter from the description of the experiences of women and girls who have had contact with Boko Haram can provide a rich and in-depth understanding of female participation in terrorism from the perspective of those involved. This effort will also help implement policy strategies that can incorporate a gender perspective into anti-terrorism efforts in Nigeria and beyond.

\section{The Present Study}

The study examines the description of the experiences of women and girls before, during, and after their contact with Boko Haram. This study seeks to explore the following: What factors influence female involvement in terrorist activity in Nigeria? Is the increase in targeted female recruitment through abduction, compulsion, or willingness essential in understanding this phenomenon? What is, therefore, the nexus or dimensions of the relationship between women, gender, and terrorism? These issues constitute the arguments which this study seeks to interrogate.

The study utilized a qualitative research design to address the following research questions:

1. How do women and girls who have had contact with Boko Haram conceptualize terrorism?

2. What family and community dynamics contribute to the involvement of women and girls in terrorism in Nigeria?

3. What are the challenges to reintegration back into society after involvement with Boko Haram?

Taking on a qualitative research approach, this study does not offer any research hypotheses. The qualitative research method was suitable for this study because it focuses on researching how women and girls who have had first-hand contact with Boko Haram perceive the concept of terrorism and female involvement in terrorist activity in Nigeria. Utilizing in-depth qualitative interviews can provide a profound and detailed understanding of female participation in terrorism in Nigeria. It also allows us to focus on the descriptions of those involved in the phenomena rather than merely studying the subject matter of female participation in terrorism in a vacuum.

The study adopted the phenomenological research approach. Phenomenology is a qualitative research method used to describe how individuals experience a specific phenomenon. Phenomenological research aims to describe a problem as accurately as possible while refraining from any pre-given framework but remaining true to the facts (Groenewald, 2004). This research design aims to examine the issue as individuals experience it and directly describe it without considering its psychological genesis or causal explanations. Examining the perceptions of women and girls with previous experiences with Boko Haram can create connections that can yield significant counter-terrorism approaches.

This study relied on data collected through semi-structured face-to-face interviews with 16 participants representing women and girls in the Boko Haram camp from 2014 to 2018. Through semi-structured interviews, the conversations were guided but allowed the participants to provide important information not necessarily reflected in the interview questions. The Snowball Sampling Method was adopted to recruit the 16 interview participants from this hard-to-identify population.

\section{Results}

Table. 1 below presents the demographic information of the participants.

Table 1. Participants' Demographic Information

\begin{tabular}{lc}
\hline Age & Number of Participants \\
\hline $18-24$ & 7 \\
\hline $25-34$ & 5 \\
\hline 35 and above & 4 \\
\hline Marital Status & 3 \\
\hline Single / Never Married & 11 \\
\hline Married to a Boko Haram member / Separated & 2 \\
\hline Widowed & 11
\end{tabular}




\begin{tabular}{lc} 
High School & 5 \\
\hline Some College & 0 \\
\hline Religious Affiliation & 1 \\
\hline Christian & 14 \\
\hline Muslim & 1 \\
\hline Other & 2 \\
\hline Geopolitical Zone of Origin & 10 \\
\hline North Central & 4 \\
\hline North East & \\
\hline North West &
\end{tabular}

A visual inspection of Table 1 shows that seven of the 16 participants interviewed were between 18- 24, five were between the ages of 25-34, and four were 35 and above. Of the 16 women interviewed, three were single, 11 were married to Boko Haram fighters, and two were widowed. In terms of education, 11 of the 16 participants had less than a High School diploma or no form of formal education; five participants had at least a High School Diploma, and none had a college or an associate degree. Most respondents were Muslim $(\mathrm{n}=14)$, one respondent self-identified as Christian, and one respondent did not identify with any religion. The interview participants were from the Northern parts of Nigeria. Of the 16 respondents, two were from the North Central political zone in Nigeria, ten were from the North East, and four were from the North West.

\subsection{List of Themes}

Quotes were selected and used to support and maintain the validity of themes. Regardless of the varying levels of educational attainment, participants were able to describe their lived experiences which enabled the identification of common themes used in this study. The identified themes were developed based on the three research questions of the study.

\subsubsection{Research Question 1: How do women and girls who have had contact with Boko Haram conceptualize terrorism?}

Conversations with respondents were started by asking them to describe what terrorism meant to them. Overall, the participants shared similar descriptions of terrorism. Interestingly, these perceptions focused on acts perpetrated by Boko Haram. The participants described terrorism as physical harm committed against their family and community members or the threat/fear of such bodily harm. Participants' awareness of ongoing violence before their contact with Boko Haram was also pivotal. Therefore, participants were asked if they knew about terrorism before their time in the camp. This question was necessary to analyze if the respondents' understanding of terrorism changed after arriving at the Boko Haram camp. For the most part, participants had a general knowledge of the level of violence in Nigeria before their time in the Boko Haram camp. Most participants emphasized that the fear of possible attack on their local communities led to their prior knowledge of Boko Haram. For instance, in response to the question, "Did you feel safe in your community before Boko Haram's captivity?" NG002 responded: "The people in my area always had the fear that one day Boko Haram will come and kill us because we knew of how they had been killing people in other areas close to us." NG009 offered a broader perspective of her understanding of terrorism, noting, "Boko Haram members used to come to my community requesting that the farmers pay their taxes [to Boko Haram]. They always said that if they did not get their money, they would come and kill all the men in the village and sell the women out in marriage. We always had the fear that this would happen."

Participants described families withdrawing their daughters from schools as the knowledge of Boko Haram spread and threats from the group intensified. They described that their families and communities responded to these threats by not educating their girls, worrying that Boko Haram would hurt them. NG005 described this in the following words "Yes, I know Boko Haram. They started opposing those people who attended school. Those whose children were attending school kept receiving a threat from them. These threats made families to be discouraged and, in turn, stopped us from going to school."

Furthermore, participants also described the knowledge of Boko Haram spreading through word of mouth and the media. A significant number of participants $(n=7)$ acknowledged the role of the media while describing the experiences they had before their contact with Boko Haram. NG001's experience captured this when she stated, "Yes, we talk about Boko Haram issues at home. My uncle was in the firewood business for a long time before Boko Haram decided to ban the 
business. The news of Boko Haram banning the firewood business spread, and everyone in my community began to fear for their lives. It was so bad that we could not talk about Boko Haram in the mosque or in public because they come after you." A significant number of participants $(\mathrm{n}=12)$ described Boko Haram's extortion of funds from local business owners in their communities. They referred to this as a form of taxation system imposed on the community by Boko Haram. Participants $(n=8)$ believed that violence in their communities was a natural consequence of the failure to comply with the threats issued by Boko Haram.

3.1.2 Research Question 2: What family and community dynamics contribute to the involvement of women and girls in terrorism in Nigeria?

Participants presented mixed responses concerning family and community dynamics. The experiences of participants who had some degree of formal education differed from those without any education. Regardless of these differences, participants' experiences touch on the active role of the community and family dynamics in female involvement in terrorist activity in Nigeria. The following sub-themes were identified: (1) Early child marriage, (2) Lack of support for education, and (3) The institutionalization of sexual slavery.

Early Child Marriage. Participants described child marriage practices while conceptualizing the role of community and family dynamics in connection to terrorism in Nigeria. NG007 stated, "The inequalities faced by women and girls in our community is in respect to the advancement of education after finishing secondary [high] school. We are usually not allowed to continue with our education; rather, our fathers chose to marry us off." The experience of NG011 touches profoundly on this issue. Nigerian security operatives arrested NG011 in 2014 after she abandoned a suicide vest in a cab. After being in police custody for almost a year, she was released to the Internally Displaced Persons (IDP) camp where she currently resides. Recounting how she got into the camp, she stated that in 2013, she was given away in marriage by her father at the age of 13. NG011 described that her father donated her and her mother to Boko Haram as a "gift, free of any monetary gains." This act led to the participation of a 13-year-old in the activities of Boko Haram.

NG001 stated, "My first contact was when they stormed our village in [name omitted]. They entered our house, and one [name omitted] indicated [an] interest in taking my sister [name omitted] and I with them as his wives. My family was initially resistant, but they threatened to kill our father." The consent of the women and girls who were married to Boko Haran fighters are typically not voluntary. NG005 stated, "Yes, I was married to [name omitted]. He married me without regard for my feelings. They took the decision and arranged the marriage without seeking my consent. I did not develop any feelings for him."

Early child marriage raises issues of violating human rights, interference with the development of the girl-child, early pregnancy, medical health complications, and compromise to education. Because of early child marriage and childbirth at a young age, many women and girls in the Boko Haram camp suffer Vesico Vaginal Fistula (VVF). The experiences of NG010 touch profoundly on this problem. She stated, "After I came out of the Boko Haram camp, I started smelling, and many people in the village began to laugh at me. I thank God for the people who came to repair me."

Furthermore, the experience of NG015 introduced a fresh perspective to the practice of early child marriage. She was abducted and married off while in the Boko Haram camp. She stated, "Yes, I did marry one [name omitted] inside the camp. Before then, I did not think of marriage at all. In the camp, the Amir (Note 1) ${ }^{\mathrm{i}}$ gave an instruction which they obeyed. He said that any Boko Haram member who had an interest in marriage could marry any girl. He can go ahead to perform the marriage rites. The dowry was a small amount that anyone could afford. They would collect that amount as dowry." The introduction of dowry payment to someone other than the parent of a bride falls outside the acceptable cultural practices of Nigerian communities. This finding may imply a neglected link between the payment of bride price (dowry) and violent conflict.

The data revealed a significant finding which has not received any media attention. Participants described a form of extortion through the imposition of taxes (Note 2) ${ }^{\mathrm{ii}}$ on business owners by Boko Haram. This practice of extortion also had a significant link to the capture of women and girls since participants stated that non-payment of the funds influenced their capture. Recounting how she got into the camp, NG007 stated, "I was taken because my father could not meet up with the payment Boko Haram wanted from his firewood business. They married me, and there was nothing my father could do." Boko Haram's imposition of a taxation system is a form of extortion from the community members. These findings emphasized a direct link between the economic disparity and forced marriages where young girls are routinely used as a means of payment whenever the families do not have other means of meeting up to Boko Haram's demands.

Lack of Support for Education. Participants described the lack of support for education as another area where family and community dynamics work to expose women and girls to violence and terrorism in Nigeria. The respondents expressed similar accounts on this issue. NG001, NG006, NG007, NG008, NG009, and NG010 emphasized that gender inequalities in their communities directly relate to the lack of access to education. The ideologies of Boko Haram about education also shape family and community dynamics in the areas where the organization operates. The group intends to 
prohibit all forms of western education, evidenced by their consistent targeting of schools where they kidnap girls to achieve their aims.

Participants $(n=10,62.5 \%)$ stated that Boko Haram's aversion to western education influenced their kidnap. NG005 described this clearly when she stated: "My first contact with them [Boko Haram] was when I was going to school in the morning and one [name omitted] approached me and insisted I go back home because they said it is a sin to attend school. The school authorities in our community were concerned because students were being warned by Boko Haram not to go to school." These findings indicate that despite having strategic and global impacts, the problem of Boko Haram is primarily a local issue, and as such, must be understood and addressed within its local contexts.

The Institutionalization of Sexual Slavery. The analysis of the data and the narration of the participants' lived experiences raise questions of Gender-Based Violence (GBV). From the study data analysis, it appears that gender is progressively an essential component of Boko Haram's operations. The experiences NG008 described touch profoundly on this issue. NG008 stated, "My marriage to Boko Haram contributed to my understanding of the sect's activities and their abusive tendencies against girls whom they take as sex tools." Similarly, NG005 stated, "I witnessed violence when I saw them kill one girl who rejected a sexual advance from one of the Boko Haram commanders. The commander shot her to death. I am still affected by what happened that day."

NG015, one of six women abducted by Boko Haram from Maiduguri, stated that: "When we were taken, the insurgents raped us repeatedly. They claimed that the rape on us as jizya." Jizya is a tax paid by Christians under Islamic law. Most respondents viewed these sexual assaults as a criminal offense even though the government has not officially classified such acts as an offense. The use of sexual slavery to ensure the participation of women and girls indicates the acceptability of the practice amongst the insurgents. Indeed, one can analyze the GBV relating to female involvement in terrorism in Nigeria by studying broader discriminatory practices targeted against women and girls within Nigeria and, indeed, sub-Saharan Africa. Terrorist groups who seek to use gender to further their ideologies and goals can exploit these gendered practices to their advantage.

3.1.3 Research Question 3: What are the challenges to reintegration back into society after involvement with Boko Haram?

Reintegration into the communities holds the key to preventing the future abductions of women and girls and their voluntary return to the Boko Haram camp. It appeared that while life with Boko Haram was difficult, most women had limited options for a dignified living after they left the camp. NG005 stated that she finds "it hard to be accepted into [the] society, and sometimes I wish I never returned." Many of the participants expressed that their experiences directly impacted their ability to pursue formal education. They also described that a lack of formal education directly impedes their ability to move on from their ordeal effectively. Participants expressed that educating women and girls would help in preventing future female participation in terrorist activities. NG002 stated, "My experience with the Boko Haram has influenced me to pursue my interest to have knowledge, and even those involve [d] in the notorious act [s] in Boko Haram are victims of illiteracy. My goal and dream now are to be able to write my Secondary [high] School final exam and, after that, to be able to further my education."

Many of the participants described suffering physical and mental health problems. Some described continuing to endure bleeding and other severe gynecological issues because of rape and childbirth at a young age. In addition to their mental and physical conditions, most participants focused on the hostile reception they received from the Nigerian society. The participants revealed that they continuously experience victimization from the members of the community. They believed that they suffered discrimination from their communities because of their abduction and stay in the Boko Haram camp. NG003 captured this in its entirety when she stated: "We do not feel really accommodated in our community. My current life is not too good either because we face a form of discrimination in our community. They tell us [that] after being saved from Boko Haram, we returned with snakes [referring to their children] from our Boko Haram husbands. I stay with my family members in [name omitted]. I don't do anything personal for a living only out of some people's generosity we survive now. My experience with Boko Haram and [my experiences] after my release only tells me not to give up in life. The head of the community here in [name omitted] has promised to help us with finances to start a trade. My religion is Islam, and I practice my faith. My goal and dream are to go back to school and possibly get assistance to support myself and the child."

This continuous victimization poses a threat to societal re-entry. The abduction and attacks on women and girls to ensure female participation in terrorism created a ripple effect that set in motion a range of negative impacts such as loss of education, early marriage, early pregnancy, and the stigma associated with sexual violence and bearing children from rape. These ills often aggravate and intensify the pre-existing forms of gender discrimination and harmful practices that negatively affect girls and women in Nigeria. 


\section{Discussions}

By capturing the experiences of women and girls who have lived in the Boko Haram camp, the study aimed to evaluate family and community factors that influence female involvement in terrorism in Nigeria. I anticipated a link between the Rational Choice Theory of Terrorism and Stockholm syndrome in explaining the motivations of women and girls to support terrorism in Nigeria. The study findings neither supported the Rational Choice Theory of Terrorism nor did it indicate the existence of Stockholm Syndrome. Participants' narrations did not establish a marked change in their perceptions of Boko Haram before and after their time in the camp. They did not show a different understanding or greater sympathy to the Boko Haram cause. Instead, they portrayed a constant feeling of distaste towards the organization. The findings of this study are discussed below based on the three research questions posed.

\subsection{Conceptualization of terrorism in Nigeria}

The first theme presented in the study represents the way participants understand the concept of terrorism in Nigeria. The results of the study parallel the existing research on this topic. Prior research establishes that the subject matter of terrorism is fluid and evolves from shared interactions with the concept (Ganor, 2002). Many of the participants in the study had a general knowledge of the existence of violence in Nigeria. Their interaction with the organization itself demonstrated their knowledge of terrorist activities. The participants' descriptions raise the question of the institutionalization of terrorism in the Northern part of Nigeria. Boko Haram's imposition of a taxation system without countermeasures by the government attests to the level of violence in Nigeria. To a large extent, this changes the dynamics in understanding the various internal funding mechanisms used by local terrorist groups. The media and the Nigerian government have yet to address this aspect of Boko Haram's operation.

Furthermore, like the position of Onapajo, Uzodike, \& Whetho (2012), many of the participants interviewed conceptualized terrorism in Nigeria from the perspective of physical harm or the threat of harm to them, their family members, and the community. These descriptions raise the question of family attachment, the correlation between individual experiences, and the overall perception of violence in Nigeria. Researchers have established that terrorist organizations exploit family ties (Collins, 1998; Schbley, 2000; Hoffman, 2002; Helmus, 2009; Mullins \& Dolnik, 2009; Chetnov-Hwang, 2012; Canter, Sarangi, \& Youngs, 2014). Nigerian society encourages strong family ties fostered by cultural practices. In the same manner, communal dynamics shape and play a massive role in the social welfare system. Curiously, family ties played a considerable role in the perceptions of the women interviewed. The participants' shared experiences evidenced that we cannot ignore family and community dynamics when discussing female participation in terrorist activities in Nigeria.

\subsection{Family and community dynamics that contribute to the involvement of women and girls in terrorism in Nigeria}

The second theme that evolved from the data centered on how family and communal dynamics influence female participation in terrorism in Nigeria. The findings indicate that family and community dynamics play a significant role in discussing female participation in terrorism in Nigeria. The study participants shared stories that suggest that the protection of the fundamental rights of women and girls can lead to lower levels of female involvement in terrorism in Nigeria. The study data also suggest that the exposure of women and girls to gender inequalities impacts female participation in terrorism in Nigeria. Findings indicated that early child marriage and the lack of support for education are the significant inequalities women and girls experience in the community, leading to the rise in female involvement in terrorism.

Interestingly, early child marriage currently represents a significant social problem in Nigeria. Northern Nigeria, where Boko Haram predominantly operates, has the highest rate of early girl child marriage (Braimah, 2014). Approximately $44 \%$ of girls are married off before their 18th birthday (Fayokun, 2015). The Nigerian Constitution provides that an individual should be 18 years or older to consent to marry legally. The Child's Rights Act of 2003 also provides that the age of consent should be 18 years old. Regardless of these legal provisions, early child marriage is still a huge issue in Nigeria. Although there is little concrete data that links the variations in the prevalence of early child marriage to the increase in female involvement in terrorist activity in Nigeria (Oke \& Labeodan, 2015), the data used in this study further establishes a relationship between the two phenomena. The interview data indicated Boko Haram's attack on schools and the kidnapping of students intensifies the tendency for girls to be married off early. The data also showed that the concern for the safety of Nigerian girls results in a discontinuation of the education of the girl child, particularly in the various conflict-prone areas.

Early child marriage influences female involvement in terrorism because it drives the family ties which terrorist organizations exploit (Collins, 1998; Schbley, 2000; Helmus, 2009; Mullins \& Dolnik, 2009; Canter, Sarangi, \& Youngs, 2014). Often, brides of early child marriages become victims of domestic violence and psychological abuse because of the significant age difference between them and their husbands (Arthur et al., 2018). These types of marriages place young women in an incredibly vulnerable position of being exploited by terrorist organizations - the findings of this study 
support this assertion. Data suggest that Boko Haram uses early child marriage practices in Northern Nigeria to its benefit. The participants' experiences indicate that while some families voluntarily marry off women and girls as a sign of solidarity to Boko Haram's cause, a significant number of brides are victims of abduction who are married off to fighters. Early child marriage often entails that the young girls forced into marriage stop going to school. The lack of education of women and girls increases the risk of early child marriage, early exposure to sexual intercourse, sexually transmitted diseases, early pregnancy, and pregnancy-related complications, which are on the rise in Nigeria (Amodu, Salami, \& Richter, 2017).

Furthermore, it is crucial to examine the relationship between Boko Haram and western education. Boko Haram stands against western education (Onuoha, 2012; Chothia, 2012). The direct translation of the organization's name from the Hausa language means, "Western education is forbidden." The meaning of the organization's name implies that the foundation upon which it operates is to fight the formal education of Nigerian youths. Therefore, it appears that eradicating western education in its entirety is at the core of Boko Haram's motivations. To this end, the adoption of early child marriage and establishing a family bond that aims to suppress Western education has been a successful strategy of the organization.

The Universal Declaration on Human Rights recognizes education as a fundamental human right. Research has found a positive correlation between the enrollment of girls in school and the gross national product and life expectancy (Schultz, 2002). Additionally, the National Policy on Education states that access to education is a right for all Nigerian children regardless of gender, religion, and disability (Akinpelu, 2007). The findings of this study indicate that women and girls in Nigeria value education and the protection of their human rights. All the study's participants suggested that educating the girl child is central to women's overall well-being in Nigerian society.

Moreover, the experiences of participants who had some level of formal education significantly differed from those who had none. Educated participants were clear in conceptualizing terrorism and conveying the importance of educating the girl-child in Nigeria. The differences in the experiences of girls abducted from schools and those abducted from their families (without formal education) stress the need to ensure the education of women and girls. Education is central to the survival of women and girls and indeed played a significant role in the experiences of the participants interviewed.

In addition, the apparent blurred lines between willing participation and the involuntary engagement in terrorism have left many women and girls bearing the stigma of association with Boko Haram. Bearing children for Boko Haram fighters further intensifies this stigma. Given the conservative nature of Nigerians, particularly those in the North-Eastern part of the country, the community highly frowns at the concept of being a single mother. As a result, some women and girls may feel trapped in the vicious circle of going back to the Boko Haram camp to avoid their community victimization. Consequently, continuous victimization represents a significant obstacle to the reintegration of women and girls into their communities. The isolation and rejection that these women face can build the kind of resistance that has led to the evolution of Boko Haram in the first place. Nigerian security operatives had previously arrested three of the participants I interviewed, but they were subsequently released. There are still women who are in police custody for their participation in terrorist activities. The lack of distinction in the treatment of victims and perpetrators represents a grey area that needs attention. Due to the sensitive nature of the subject matter, it is difficult to ascertain the level of willingness or coercion in the participation of women and girls. Future research can build on this area.

\subsection{Challenges to reintegration back into society after involvement with Boko Haram}

The findings of this study indicate that reintegration into society continues to pose a threat to women and girls who had contact with Boko Haram. Adopting effective reintegration strategies is necessary to ensure that these women and girls do not find reasons to go back to the Boko Haram camp. It is essential to sensitize the public and communities to the plights of the survivors of Boko Haram and violence in Nigeria. The government needs to prioritize educating the members of communities that receive survivors on accepting and treating them with compassion. This step will facilitate the proper reintegration of women and girls into their communities. Religious leaders who play significant roles in Nigerian communities should be encouraged to use their positions to appeal to the public to show support to the survivors of terrorism in Nigeria. To ensure reintegration, the government needs to provide women and girls with the necessary physical and mental health services that they may need to ensure resilience-building and surviving life after their Boko Haram encounter.

Furthermore, the survivors of Boko Haram face many physical and mental health problems, such as the forcible displacement from their homes and having to live in the Internally Displaced Persons (IDP) camps. Except for three participants, the other 13 interviewees reside in shelters created for internally displaced persons. While in the field, I observed that surviving the Boko Haram camp marks the beginning of their ordeals. Some of the participants revealed having continuous nightmares related to their stay in the Boko Haram camp. The fact that some of their counterparts remain missing does not help issues. Most of the study participants face visible emotional and behavioral trauma. Six of 
the study participants were battling VVF because of the exposure to early child marriage, sexual violence, and childbirth. My conversations with the victims revealed that the community discriminates against the women and girls who suffer VVF by treating them as outcasts and refusing to communicate with them. There is a need to offer more protection to women and girls against violence perpetrated by organizations like Boko Haram. The Nigerian government, both at the state and federal levels, and international efforts aimed at countering Boko Haram attacks should pay more attention to the vulnerable populations that are susceptible to victimization.

There were a few limitations to this study. The study examined the experiences of 16 women out of a large population of females who have had contact with Boko Haram. While this number of in-depth semi-structured interviews provides an excellent data source sufficient to reach saturation in a phenomenological study of this kind, more interviews with the target population located in other parts of Nigeria are required to allow the generalization of findings to the larger population.

Additionally, memory and perceptions can become skewed due to the limited amount of information a person can remember over time (Brewin, 2001). As a result, we can question the accuracy of the memories narrated after time has elapsed. Since I asked the participants to recall their experiences before, during, and after their time in the Boko Haram camp, it is difficult to know what aspect of their experiences participants overlooked. Prior literature suggests that people may sometimes alter their acuities of experiences to explain or fit them into present ideal versions that account for the past (Jorgensen, 2009; Vagle, 2018). As a result, participants can minimize their roles in the Boko Haram camp to protect their image and present living circumstances. Given the sensitive nature of the subject matter of this study, the participants may have been motivated to project themselves in a particular manner. They may have also been motivated to protect themselves from further victimization. For this reason, there is a possibility that some of the women interviewed may have experienced greater victimization or were more actively engaged in activities while in the Boko Haram camp. These limitations are likely to affect the findings of this study.

While exploring how the participants experience and understand terrorism in the Nigerian context, the study's findings further investigate the relationship and connectivity between female participation in terrorism, cultural practices, religion, and gender-based violence in Nigerian communities. Future studies can adopt additional focus, different research methodologies, and expanded sample size to investigate female involvement in terrorist activity in Nigeria. These aspects are necessary to understand the subject matter further, thereby bridging the gaps in existing scholarly literature. This study offers a baseline that now encourages further exploration.

\section{Conclusion}

This study aimed to introduce the importance of further exploration of gender within terrorism to understand and ultimately prevent the ongoing and escalating violence in Nigeria. The study contributes to the burgeoning scholarly literature on Boko Haram's activities in Nigeria and focuses on the gender-based approach of the organization's strategies. The analysis of female participation in violence in Nigeria remains limited by the lack of research into the experiences of women and girls found to collaborate with terrorists. There is a need for more research with women who were in captivity or have collaborated with terrorists to ascertain their views and motivations. Understanding how women experience the conflict in Nigeria not only as victims but also as actors can directly inform policies and programs aimed at tackling insurgency at the roots. This effort can also facilitate women's contribution to lasting peace.

There is little knowledge of Boko Haram's motivation for abducting girls from schools and the kidnapping of school-aged girls from their villages. Regardless, the impact these abductions have on girls and young women is immeasurable. Many of the attacks carried out by women and girls on behalf of Boko Haram have been suicide bombings. The word suicide bomber, in this case, may be a misnomer because it implies that the perpetrator has the voluntary decision to be a martyr. Their involvement in terrorist activities essentially blurs the line between perpetration and victimization. Sadly, the focus is on the former and not the latter. Consequently, there is a need to acknowledge survivors' prior and repeated victimization during reintegration into society.

The involvement of women and girls in violence indicates a change in the trend of violent conflicts that have plagued Nigeria and countries worldwide. The failure to curtail the proliferation of this issue will lead to the continued existence of Boko Haram and the unrelenting kidnapping and recruitment of women and girls as voluntary or coerced supporters, sympathizers, and participants in the wave of terror that is plaguing Nigeria.

Female participation in terrorism in Nigeria, whether due to voluntary sign up, Stockholm Syndrome, abduction, or otherwise, warrants further investigation. To better understand the subject matter of terrorism, it would be beneficial to deepen our understanding of what motivates women and girls to participate in terrorism in Nigeria. Further research into how women and girls define and participate in terrorist activity would provide policymakers in Nigeria and beyond a roadmap that allows for implementing practices at the local, national, and international levels. This endeavor would greatly influence a gendered perspective in the study of terrorism and the presentation of counter-terrorism practices. 
Given the findings of this research, the Nigerian government needs to emphasize the inclusion of gender-related considerations in the prevention of terrorism in Nigeria. There is a strong need to implement a national strategy that focuses on including women's roles in counter-terrorism attempts. This effort is instrumental in understanding how a gender perspective relates to victimization and radicalization. This effort will lead to the development of security policies that take gender in terrorist organizations into account. Tackling these parallel and interrelated facets will likely yield a significant result in preventing female involvement in terrorism.

Additionally, Nigerian families and communities are responsible for creating an environment that protects women and girls from gender-based violence. The findings of this study suggest that cultural practices drive family and community dynamics, which have a significant impact on female participation in terrorism in Nigeria. Placing the much-needed priority on the protection of the rights of the girl-child can benefit the entire nation. Families should intentionally make efforts to ensure that the female members of their unit receive a formal education. This effort will ensure the protection of a vast array of human rights. Similarly, the members of the relocation communities where survivors resettle must be sensitized to encourage the successful reintegration of individuals who come out from the Boko Haram camp. The fair treatment of these women and girls is necessary to prevent the further victimization of individuals who have suffered severe trauma during captivity.

Lastly, there is a need for continued dialogue with those women and girls who have been in the Boko Haram camp as perpetrators, witnesses, and victims. Their insights are valuable in addressing the growing female participation in terrorist activity that has impacted counter-terrorism measures in Nigeria and globally. Other potential research should examine the female victimization aspect of terrorism in Nigeria. The existence of a blurred line between perpetration and victimization should influence the treatment of women and girls who have had contact with Boko Haram. Efforts that could assist in identifying deeper motivations for female involvement in terrorism and the plight of potential victims are encouraged. It would also yield significant value to consider the influences geography, religion, family practices, and formal education may have on female involvement in terrorism in Nigeria.

\section{References}

Adorjan, M., Christensen, T., Kelly, B., \& Pawluch, D. (2012). Stockholm syndrome as vernacular resource. The Sociological Quarterly, 53(3), 454-474.

Agara, T. (2015). Gendering terrorism: Women, gender, terrorism and suicide bombers. International Journal of Humanities and Social Science, 5(6), 115-125.

Akinpelu, F. O. (2007). 'Dr'girl-child education: A reality or a mirage among females with hearing impairment in Nigeria. International Journal of the Humanities, 5(3).

Amodu, O. C., Salami, B., \& Richter, S. (2017). Obstetric fistula and sociocultural practices in Hausa community of Northern Nigeria. Women and Birth, 30(5), e258-e263.

Anderton, C. H., \& Carter, J. R. (2005). On rational choice theory and the study of terrorism. Defence and Peace Economics, 16(4), 275-282.

Arthur, M., Earle, A., Raub, A., Vincent, I., Atabay, E., Latz, I., ... \& Heymann, J. (2018). Child marriage laws around the world: minimum marriage age, legal exceptions, and gender disparities. Journal of women, politics \& policy, 39(1), 51-74.

Awa, P. M, (2020) The Prevalence and Nature of Terrorist Attacks during the Presidency of Goodluck Jonathan in Nigeria International Journal of Law and Public Administration 3(2):50.

Aziz, S. F. (2017). Losing the War of Ideas: A Critique of Countering Violent Extremism Programs. Tex. Int'l LJ, 52, 255.

Barkindo, A., Gudaku, B.T., \& Wesley, C.K. 2013. Boko Haram and gender-based violence against Christian women and children in north-eastern Nigeria since 1999. NPV RN working paper No. 1 (Amsterdam: Open Doors International).

Berrebi, C. (2009). The Economics of Terrorism and Counterterrorism: What Matters and Is Rational-Choice Theory Helpful?. Social science for counter-terrorism: Putting the pieces together, 151-208.

Bloom, M., \& Matfess, H. (2016). Women as Symbols and Swords in Boko Haram's Terror. Prism: a Journal of the Center for Complex Operations, 6(1), 104.

Brewin, C. R. (2001). A cognitive neuroscience account of posttraumatic stress disorder and its treatment. Behaviour research and therapy, 39(4), 373-393.

Canter, D., Sarangi, S., \& Youngs, D. (2014). Terrorists' personal constructs and their roles: A comparison of the three I 
slamic terrorists. Legal and Criminological Psychology, 19(1), 160-178.

Chernov-Hwang, J. (2012). Terrorism in perspective: an assessment of'Jihad Project'trends in Indonesia.

Chothia, F. (2012). Who are Nigeria's Boko Haram Islamists. BBC News, 11.Collins, P. H. (1998). It's all in the family: Intersections of gender, race, and nation. Hypatia, 13(3), 62-82.

Cunningham, K. J. (2003). Cross-regional trends in female terrorism. Studies in conflict and terrorism, 26(3), 171-195.

Cunningham, K. J. (2007). Countering female terrorism. Studies in Conflict \& Terrorism, 30(2)

Fayokun, K. O. (2015). Legality of child marriage in Nigeria and inhibitions against realization of education rights. US-China L. Rev., 12, 812.

Ganor, B. (2002). Defining terrorism: Is one man's terrorist another man's freedom fighter? Police Practice and Research, 3(4), 287-304.

Groenewald, T. (2004). A phenomenological research design illustrated. International journal of qualitative methods, 3(1), 42-55.

Helmus, T. C. (2009). Why and how some people become terrorists. Social science for counter-terrorism, 74(06-C), 71.

Hoffman, B. (2002). Rethinking terrorism and counter-terrorism since 9/11. Studies in Conflict and Terrorism, 25(5), 303-316.

Human Rights Watch (2014, October). Those Terrible Weeks in their Camp, Boko Haram Violence against Women and Girls in Northeast Nigeria. Human Rights Watch. Retrieved on 08/18/2019 from: http://features.hrw.org/features/HRW_2014_report/Those_Terrible_Weeks_in_Their_Camp/assets/nigeria1014web. pdf

Jorgensen, E. R. (2009). On thick description and narrative inquiry in music education. Research Studies in Music Education, 31(1), 69-81.

Lord-Mallam, N. C. (2019). Women and Terrorism in Nigeria. In The Impact of Global Terrorism on Economic and Political Development: Afro-Asian Perspectives (pp. 321-340). Emerald Publishing Limited.

Maiangwa, B., \& Agbiboa, D. (2014). Why Boko Haram kidnaps women and young girls in North-Eastern Nigeria. Conflict Trends, 2014(3), 51-56.

Maiangwa, B., \& Amao, O. B. (2015). "Daughters, brides, and supporters of the Jihad": revisiting the gender-based atrocities of Boko Haram in Nigeria. African Renaissance, 12(2), 117-144.

Mullins, S., \& Dolnik, A. (2009). Terrorist networks and small group psychology. The Faces of TerrorismMultidisciplinary Perspectives, West Sussex: John Wiley \& Sons Ltd, 137-150.

Ness, C. D. (Ed.). (2007). Female terrorism and militancy: agency, utility, and organization. Routledge.

Ochberg, F. M., \& Soskis, D. A. (Eds.). (1982). Victims of terrorism. Boulder, CO: Westview Press.

Oke, R. O., \& Labeodan, H. A. (2015). Boko Haram Insurgence, the Chibok Girls' Abduction and the Implication for the Girl Child in Nigeria. Unraveling and Reweaving the Sacred Canon in Africana Womanhood, 93-106.

Onapajo, H., Uzodike, U. O., \& Whetho, A. (2012). Boko Haram terrorism in Nigeria: The international dimension. South African Journal of International Affairs, 19(3), 337-357.

Onuoha, F. C. (2012). Boko Haram: Nigeria's Extremist Islamic Sect. Al Jazeera Centre for Studies, 29(2), 1-6.

Osita-Njoku, A., \& Chikere, P. (2015). Consequences of Boko Haram terrorism on women in Northern Nigeria. Applied Research Journal, 1(3), 101-107.

Pape, R. A. (2006). Dying to win: The strategic logic of suicide terrorism. Random House Incorporated.

Schbley, A. H. (2000). Torn between God, family, and money: The changing profile of Lebanon's religious terrorists. Studies in Conflict \& Terrorism, 23(3), 175-196.

Schultz, T. P. (2002). Why governments should invest more to educate girls. World Development, 30(2), 207-225.

Sjoberg, L., \& Gentry, C. E. (Eds.). (2011). Women, gender, and terrorism. University of Georgia Press.

Steward, S. (2015). An Unprecedented Use of Female Suicide Bombers. Stratfor, October, 23. Retrieved on 08/19/2019 from:

africa/nigeria/what-would-make-woman-go-back-boko-haram-despair.

Talbot, R. (2000). Myths in the representation of women terrorists. Eire-Ireland, 35(3), 165-186. 
Turshen, M. 2000. The political economy of violence against women during armed conflict in Uganda. Social Research. 67(3): 803-824.

Vagle, M. D. (2018). Crafting phenomenological research. Routledge.

Zenn, J., \& Pearson, E. (2014). Women, gender and the evolving tactics of Boko Haram. Journal of terrorism research.

\section{Copyrights}

Copyright for this article is retained by the author(s), with first publication rights granted to the journal.

This is an open-access article distributed under the terms and conditions of the Creative Commons Attribution license which permits unrestricted use, distribution, and reproduction in any medium, provided the original work is properly cited.

i “Amir" refers to the head community chief in Northern Nigeria.

ii Taxes in this regard do not refer to those imposed by the government. Instead, it is a form of extortion of funds from the community members by Boko Haram as a source of funding for the organization. 